\title{
The tadpole of Hypsiboas atlanticus (Anura, Hylidae) from northeastern Brazil
}

\author{
Filipe A. C. do Nascimento ${ }^{1}$, Marcelo G. de Lima ${ }^{1,2}$, Gabriel O. Skuk ${ }^{1,3}$ \& Rafael O. de Sá ${ }^{4}$
}

1. Setor de Zoologia, Museu de História Natural, Universidade Federal de Alagoas, 57051-090 Maceió, Alagoas, Brazil. (filipe.bio@uol.com.br)

2. Departamento de Zoologia, Universidade Federal de Pernambuco, Programa de Pós-graduação em Biologia Animal, 50670-420, Recife, Pernambuco, Brasil. (delimamg@yahoo.com.br)

3. Setor de Biodiversidade e Ecologia, Instituto de Ciências Biológicas e da Saúde, Universidade Federal de Alagoas, $57010-020$ Maceió, Alagoas, Brazil. (gabrielskuk@ terra.com.br)

4. Department of Biology, University of Richmond, Richmond, Virginia 23173, USA. (rdesa@ richmond.edu)

\begin{abstract}
The tadpole of Hypsiboas atlanticus (Caramaschi \& Velosa, 1996) is described from the municipality of Maceió, State of Alagoas, Brazil. At stage 36 the larvae have an overall elliptical body in lateral and dorsal views, oral disc anteroventral, spiracular tube sinistral, and labial tooth row formula $2(1,2) / 3(1)$. The oral disc is surrounded, almost completely (anterior medial gap present) by a single row of marginal papillae. Described tadpoles of the H. punctatus species group can be differentiated by a combined disc oral features. Additional descriptions of $H$. punctatus (Schneider, 1799) tadpoles from populations throughout South America may be helpful in determining the status of these populations.
\end{abstract}

KEYWORDS. Amphibia, Hypsiboas, larval forms, internal oral anatomy, Atlantic Rain Forest.

RESUMO. O girino de Hypsiboas atlanticus (Anura, Hylidae) do nordeste do Brasil. O girino de Hypsiboas atlanticus (Caramaschi \& Velosa, 1996) é descrito a partir de indivíduos coletados em Maceió, Estado de Alagoas, Brasil. No estágio 36 o corpo é elíptico em vistas lateral e dorsal, o disco oral é anteroventral e o espiráculo é sinistro. A fórmula dental é $2(1,2) / 3(1)$. O disco oral é rodeado por uma única fileira de papilas marginais, ausentes anteriormente. Os girinos do grupo de $H$. punctatus podem ser diferenciados por um conjunto de características do disco oral. Descrições adicionais de girinos de populações de H. punctatus (Schneider, 1799) em toda América do Sul poderá ser útil em determinar seus status.

PALAVRAS-CHAVE. Amphibia, Hypsiboas, formas larvais, anatomia oral interna, Floresta Atlântica.

The genus Hypsiboas Wagler, 1930 was resurrected by FaIVOVICH et al. (2005) based on molecular evidence to accommodate all species formerly included in the Hyla albopunctata, $H$. boans, $H$. geographica, $H$. granosa, $H$. pulchella, and $H$. punctata species groups, the $H$. albomarginata complex, and several species previously unassigned to any group. Kolenc et al. (2008) provided a summary of the main external morphology traits and oral cavity features of Hypsiboas tadpoles, including the $H$. punctatus group; however, the study did not provide synapomorphies for the genus Hypsiboas. Following Faivovich et al. (2005), the former $H$. granosa and $H$. punctata groups form a monophyletic group named Hypsiboas punctatus species group: H. alemani (Rivero, 1964), H. atlanticus (Caramaschi \& Velosa, 1996), $H$. cinerascens (Spix, 1824), H. hobbsi (Cochran \& Goin, 1970), $H$. jimenezi Señaris \& Ayarzagüena, 2006, $H$. ornatissimus (Noble, 1923), H. picturatus (Boulenger, 1899), H. punctatus (Schneider, 1799) and H. sibleszi (Rivero, 1972) (Faivovich et al., 2005; Señaris \& Ayarzagüena, 2006).

Hypsiboas punctatus is highly variable in coloration, but predominantly green (DuELLMAN, 1974); it is found in Guyana and Trinidad, in the Amazon Basin of Ecuador, Peru, Bolivia, and Brazil, in the Orinoco Basin of Venezuela and Colombia, at Central Brazil and Chaco areas of Paraguay and Argentina (Frost, 2009). Although DuELLMAN (1974) considered a single species throughout its range and called it $H$. punctatus, the color variability and extensive geographic distribution of this taxon resulted in a nomenclatorial confusion (see CARAMASCHI \& Velosa, 1996, for names applied to this taxon throughout its range).

Hypsiboas atlanticus was described for the populations from northeastern Brazil, previously referred as $H$. punctatus. This species is closely related to $H$. punctatus, but differs in its larger head and shorter snout, two short and contiguous groups of vomerian teeth (elongated and separated in H. punctatus), and approximately circular choanae (elliptical and elongated in H. punctatus) (CARAmaschi \& Velosa, 1996); the species inhabits open flooded areas in the Atlantic Rain Forest from the State of Pernambuco to southern State of Bahia (CARamaschi \& Velosa, 1996; Santos \& Carnaval, 2002; Silvano \& Pimenta, 2002). Herein, we describe the external morphology and the internal oral anatomy of the tadpole of $H$. atlanticus and compared it with the tadpole of $H$. punctatus and with others species of the group with described tadpoles.

\section{MATERIAL AND METHODS}

Tadpoles were collected at the Mata do Catolé $\left(9^{\circ} 32^{\prime} \mathrm{S} ; 35^{\circ} 47^{\prime} \mathrm{W}\right)$, a remnant of Atlantic Rain Forest situated in the municipality of Maceió, State of Alagoas, northeastern Brazil, in August and December 2005, and January and February 2006. The tadpoles were collected with a dip net, carried to the laboratory where they were 
anesthetized in $0.1 \%$ chloretone and preserved in $5 \%$ formalin (commercial grade), except two specimens that were kept alive until they reached metamorphosis and compared with adults for species identification. The measurements and remarks on ontogenetic changes were based on 31 tadpoles ranging from stages 27 to 41 (GOSNER, 1960); tadpole description and illustration were based on a specimen at stage 36. Terminology and measurements follow Altig (1970) and Altig \& MCDiARMID (1999), with exception of interorbital distance, which was taken between the inner edges of the eyes. All measurements were taken using an ocular micrometer installed on a stereomicroscope, except for total length, height, and width of the body, which were measured with calipers $(0.01 \mathrm{~mm})$. For description of internal oral anatomy, one tadpole at stage 36 was dissected for scanning electronic microscope analysis. Specimen was prepared following Sá et al. (2007) and terminology follows Wassersug (1976) and Wassersug \& Heyer (1988). All specimens examined are deposited at the Museu de História Natural, Universidade Federal de Alagoas, Brazil (MUFAL 2969, 3775, 3776, 4755, 6481, 7160).

\section{RESULTS AND DISCUSSION}

External morphology. Illustrated tadpole (stage 36, MUFAL 7160, Figs. 1-4) measures (in mm): total length
36.2 , body length 13.1 , body height 6.3 , body width 7.0 , tail length 23.1, tail height 7.3, dorsal fin height 2.6, ventral fin height 1.6, tail musculature height 3.7, snout-nostril distance 1.2 , internostril distance 2.0 , nostril-eye distance 1.1, eye diameter 1.7, interorbital distance 3.5, oral disc width 2.7, spiracle length 1.8 , and anal tube length 3.1. Body elliptical in lateral, dorsal, and ventral views, longer than high; maximum body height near the spiracle, maximum width behind of the eyes. In this specimen, body length about $36 \%$ of total length. Snout slightly arched in lateral view, rounded in dorsal and ventral views. Eyes dorsolateral, directed laterally, situated at the end of the first third of body, eyes correspond to about 48.6 $\%$ of the interorbital distance and $4.6 \%$ of the body length. Nostrils kidney-shaped, situated halfway between the tip of snout and eyes, internostril distance about $57 \%$ of interorbital distance, external opening directed anterolaterally, the medial rim of the external nares possessing a cutaneous extension (Figs. 5, 6). Spiracle sinistral, lateral, located at the end of the middle third and below the main horizontal axis of the body, with opening directed posteriorly and inner wall present as a slight ridge. Anal tube wide, medial, with a dextral opening, and a skin-fold connecting the body with the ventral fin. Oral disc anteroventral, representing $38.7 \%$ of the body width, with two emarginations on the lower labium. A single row of marginal papillae, with a gap on the upper labium;

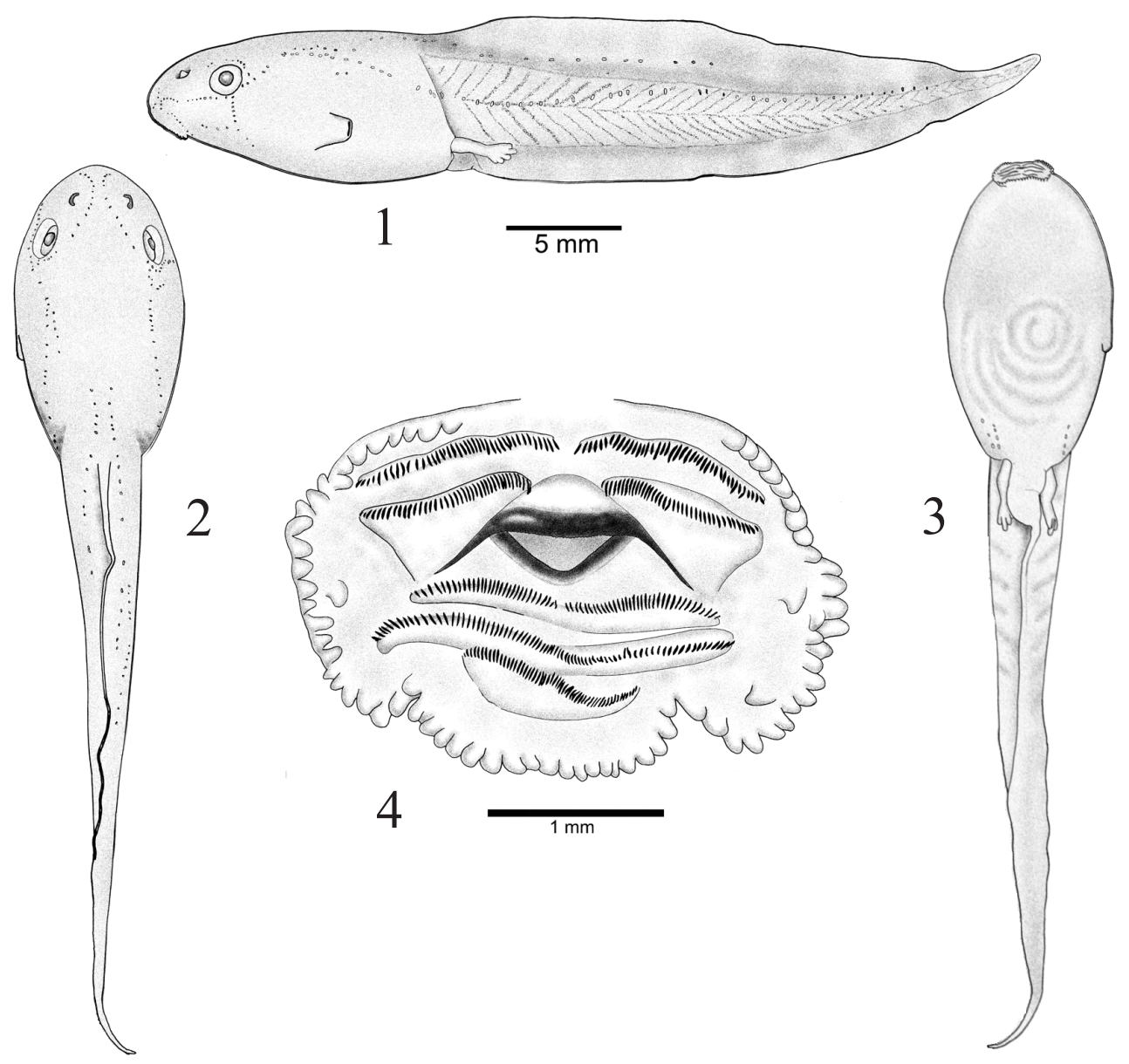

Figures 1-4. Tadpole of Hypsiboas atlanticus (Caramaschi \& Velosa, 1996) (MUFAL 7160) at stage 36 (Gosner, 1960). 1, lateral view; 2 , dorsal view; 3 , ventral view; 4 , oral disc. 
scattered submarginal papillae on posterolateral and lateral areas of oral disc. Labial tooth row formula (LTRF) 2(1,2)/3(1). A-1 and A-2 of approximately equal length; A-1 with a short medial gap approximately five teeth wide; A-2 with a medial gap about four times wider than that of A-1. P-1 with a narrow medial gap (two teeth wide). P-1 somewhat smaller than P-2; P-3 about one-third the length of P-2. Jaw sheaths pigmented and finely serrate; upper jaw arch-shaped; lower jaw V-open shaped. Caudal musculature well developed, becoming progressively thinner caudally. Maximum caudal height greater than the body height. Miosepta partially visible. Dorsal fin higher and more curved than ventral fin, beginning behind the body; ventral fin beginning at posterior edge of the body; tail ending narrow and acute. A summary of larval measurements is provided in table I.

Coloration. In life, dorsum and lateral surfaces of body dark brown; ventral surface appears lighter. Caudal musculature light brown and caudal fins almost transparent; developing limbs and anal tube similar to
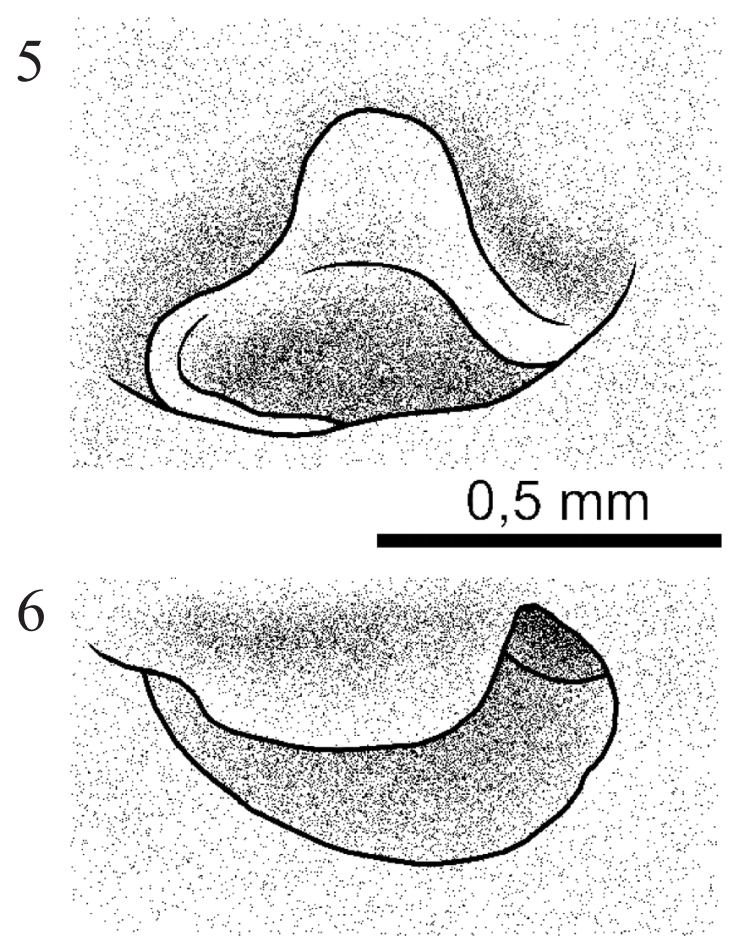

Figures 5,6. Narial opening of the tadpole of Hypsiboas atlanticus (Caramaschi \& Velosa, 1996) (MUFAL 7160) at stage 36 (Gosner, 1960). 5, lateral view; 6 , dorsal view. body coloration (Fig. 7). Color in preservative is similar to live coloration, except on the ventral surface of the body where the intestine becomes partially visible.

Variation. Variation of tadpole external morphology was observed in the oral disc of one individual, which showed an atypical labial tooth row formula $2(2) / 2(1,2)$ (MUFAL 6481, stage 37).

Remarks. At stage 25 the oral disc already showed the characteristic LTRF whereas by stage 41 only vestiges of $\mathrm{P}-1$ remained visible; the anal tube disappears and the coloration becomes clearer.

Internal oral anatomy. Hypsiboas atlanticus has an overall circular roof, with a relatively small prenarial arena. A blunt, rectangular-shaped ridge in the prenarial arena. Nares wide, oriented in an oblique angle (about $45^{\circ}$ ), placed about one-third way back on the buccal roof (Fig. 8). Anterior edge of each naris with a low narial wall, its rim bearing equally distanced prenarial papillae; posterior narial edge with an extensive, posteriorly convex narial valve; without narial-valve projections. Postnarial arena simple, with pustulations scattered over the entire area (about 25 pustulations); anterior pustulations shorter and gradually increase in size towards the medial ridge; the ones closer to the median ridge could be considered postnarial papillae. Median ridge large, with papillae on the free edge; overall the medial ridge has three "peaks" with the medial one being the taller. Lateral ridge papillae single, simple, conical, oriented transversely on each side of the median ridge. Buccal roof arena (BRA) rounded, wide, bounded anteriorly by the median ridge and latero-posteriorly by a row of pustulations forming a wide $\mathrm{V}$-shaped edge. The BRA field is evenly scattered with pustulations. Dorsal velum long, curving gradually towards the midline. Glandular zone present on the edge of the dorsal velum, clearly separated from the BRA by an area without pustulations or glands. Buccal floor overall triangular, broad (Fig. 9). Two pairs of infralabial papillae present, the most anterior pair slightly oblique but almost perpendicular to the transversely oriented second pair. First pair of infralabial papillae deeply forked, with a larger posterior branch. Second infralabial papilla divided into four blunt papillae connected basally. Although not clearly distinct (due to damage during SEM preparation), it seems that four attenuate lingual papillae are present. Buccal floor arena (BFA) U-shaped, with small and medium size pustulations homogenously scattered within the BFA; a few smaller papillae present among these pustulations. Velar surface free, relative short, in a smooth

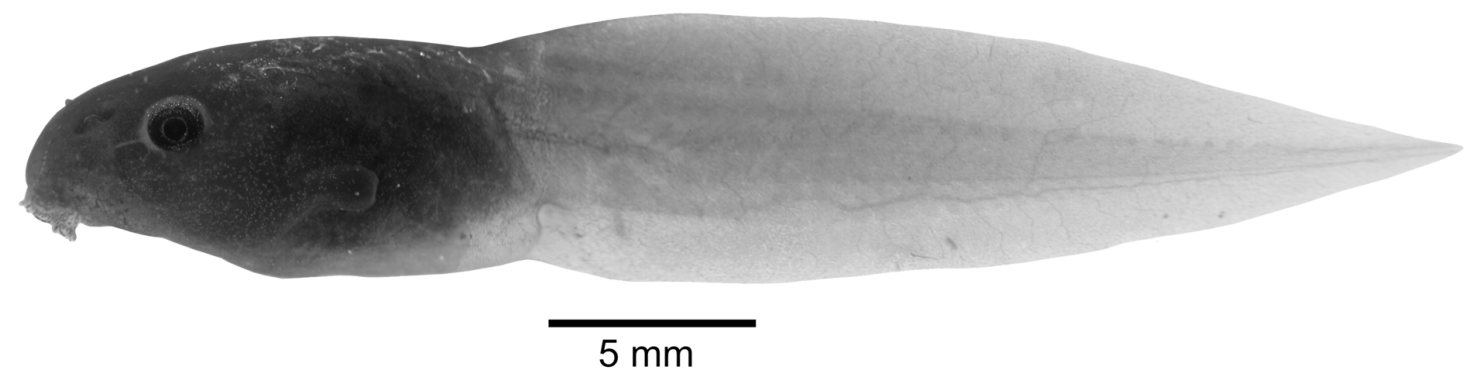

Figure 7. Tadpole of Hypsiboas atlanticus (Caramaschi \& Velosa, 1996) (MUFAL 7160) at stage 31 (Gosner, 1960). 
Table I. Measurements (in mm) of Hypsiboas atlanticus (Caramaschi \& Velosa, 1996) larvae (mean \pm standard deviation).

\begin{tabular}{|c|c|c|c|c|c|c|c|}
\hline Character & $\begin{array}{c}\text { Stage } 27 \\
(\mathrm{~N}=8)\end{array}$ & $\begin{array}{c}\text { Stage } 29 \\
(\mathrm{~N}=5)\end{array}$ & $\begin{array}{c}\text { Stage } 34 \\
(\mathrm{~N}=2)\end{array}$ & $\begin{array}{c}\text { Stage } 35 \\
(\mathrm{~N}=2)\end{array}$ & $\begin{array}{c}\text { Stage } 37 \\
(\mathrm{~N}=7)\end{array}$ & $\begin{array}{c}\text { Stage } 40 \\
(\mathrm{~N}=4)\end{array}$ & $\begin{array}{c}\text { Stage } 41 \\
(\mathrm{~N}=3)\end{array}$ \\
\hline Total length & $25.25 \pm 6.72$ & $31.88 \pm 1.47$ & $34.26 \pm 5.24$ & $35.85 \pm 0.86$ & $35.77 \pm 1.99$ & $38.35 \pm 2.48$ & $41.75 \pm 3.10$ \\
\hline Body length & $8.22 \pm 2.22$ & $10.24 \pm 0.49$ & $10.22 \pm 1.81$ & $11.35 \pm 0.00$ & $10.63 \pm 0.42$ & $11.90 \pm 0.86$ & $12.85 \pm 0.41$ \\
\hline Body height & $4.13 \pm 1.17$ & $5.03 \pm 0.30$ & $4.38 \pm 0.73$ & $4.56 \pm 0.25$ & $4.41 \pm 0.76$ & $4.31 \pm 0.90$ & $5.06 \pm 0.61$ \\
\hline Body width & $5.13 \pm 1.47$ & $6.42 \pm 0.47$ & $5.94 \pm 0.53$ & $6.29 \pm 0.32$ & $6.13 \pm 0.24$ & $6.60 \pm 0.94$ & $7.17 \pm 0.71$ \\
\hline Tail length & $17.03 \pm 4.53$ & $21.64 \pm 1.28$ & $24.04 \pm 3.43$ & $24.49 \pm 0.85$ & $25.13 \pm 1.95$ & $26.45 \pm 2.55$ & $28.89 \pm 2.70$ \\
\hline Tail height & $4.85 \pm 1.18$ & $6.32 \pm 0.26$ & $6.30 \pm 1.41$ & $6.68 \pm 0.45$ & $6.01 \pm 0.69$ & $6.40 \pm 1.00$ & $6.63 \pm 1.43$ \\
\hline Dorsal fin height & $1.75 \pm 0.43$ & $2.24 \pm 0.18$ & $1.95 \pm 0.64$ & $2.15 \pm 0.07$ & $1.81 \pm 0.21$ & $2.10 \pm 0.42$ & $1.90 \pm 0.60$ \\
\hline Ventral fin height & $1.35 \pm 0.42$ & $1.70 \pm 0.16$ & $1.30 \pm 0.42$ & $1.50 \pm 0.14$ & $1.20 \pm 0.18$ & $1.22 \pm 0.40$ & $1.33 \pm 0.45$ \\
\hline Tail musculature height & $2.48 \pm 0.69$ & $2.88 \pm 0.22$ & $3.30 \pm 0.42$ & $3.50 \pm 0.14$ & $3.13 \pm 0.48$ & $3.35 \pm 0.67$ & $3.70 \pm 0.17$ \\
\hline Snout-nostril distance & $1.04 \pm 0.27$ & $1.24 \pm 0.13$ & $1.60 \pm 0.28$ & $1.45 \pm 0.07$ & $1.51 \pm 0.12$ & $1.55 \pm 0.12$ & $1.40 \pm 0.17$ \\
\hline Internostril distance & $1.41 \pm 0.33$ & $1.70 \pm 0.10$ & $1.75 \pm 0.35$ & $1.90 \pm 0.14$ & $1.77 \pm 0.24$ & $1.82 \pm 0.18$ & $1.37 \pm 0.30$ \\
\hline Nostril-eye distance & $0.76 \pm 0.24$ & $0.98 \pm 0.09$ & $0.80 \pm 0.14$ & $0.95 \pm 0.07$ & $0.86 \pm 0.09$ & $0.85 \pm 0.12$ & $1.20 \pm 0.00$ \\
\hline Eye diameter & $0.98 \pm 0.23$ & $1.26 \pm 0.09$ & $1.45 \pm 0.07$ & $1.50 \pm 0.00$ & $1.60 \pm 0.08$ & $1.80 \pm 0.08$ & $1.87 \pm 0.25$ \\
\hline Interorbital distance & $2.37 \pm 0.51$ & $3.10 \pm 0.10$ & $3.15 \pm 0.49$ & $3.20 \pm 0.14$ & $3.38 \pm 0.17$ & $3.57 \pm 0.17$ & $3.67 \pm 0.23$ \\
\hline Oral disc width & $1.90 \pm 0.38$ & $2.36 \pm 0.15$ & $2.20 \pm 0.42$ & $2.45 \pm 0.21$ & $2.34 \pm 0.13$ & $2.60 \pm 0.29$ & $2.47 \pm 0.35$ \\
\hline Spiracle length & $1.00 \pm 0.32$ & $1.12 \pm 0.11$ & $1.35 \pm 0.21$ & $1.25 \pm 0.07$ & $1.23 \pm 0.38$ & $1.35 \pm 0.19$ & $0.67 \pm 0.25$ \\
\hline Anal tube length & $1.68 \pm 0.65$ & $2.06 \pm 0.35$ & $1.55 \pm 0.21$ & $1.30 \pm 0.28$ & $1.58 \pm 0.48$ & $1.10 \pm 0.29$ & \\
\hline
\end{tabular}
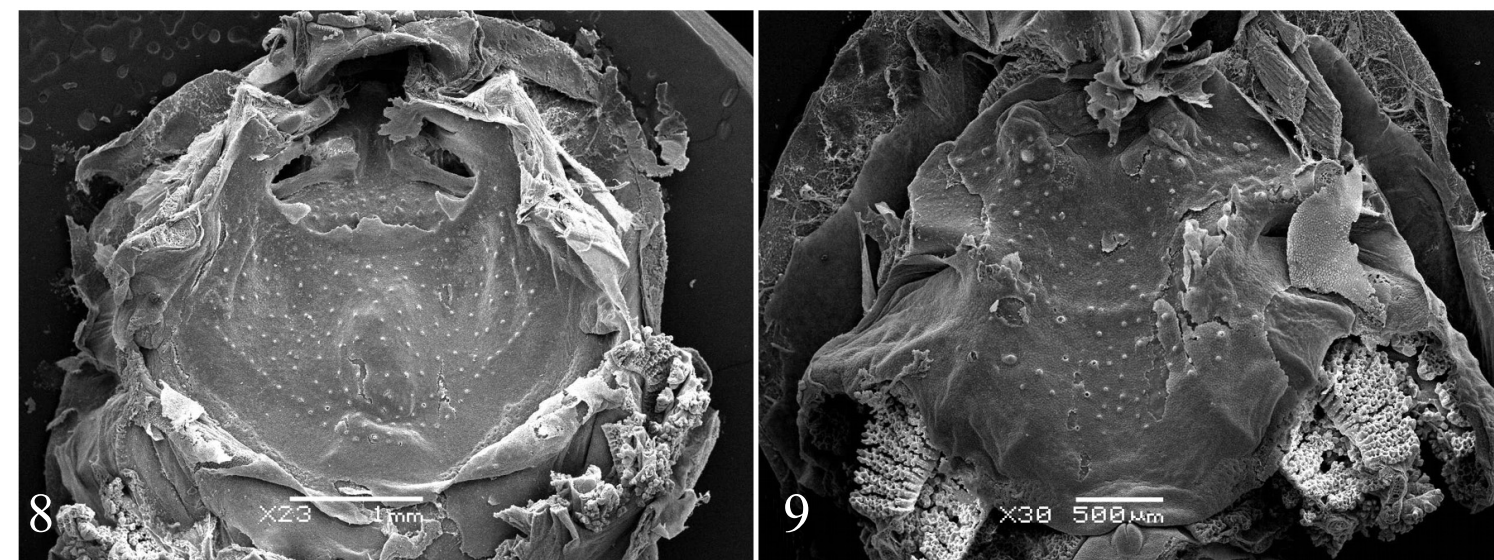

Figures 8,9. Internal oral anatomy of the tadpole of Hypsiboas atlanticus (Caramaschi \& Velosa, 1996) (MUFAL 7160) at stage 36 (Gosner, 1960), scanning electron photograph: 8, buccal roof; 9, buccal floor.

posterior margin. Median notch barely noticeable, secretory pits present, not extensive, mostly limited to posterolateral edges. Gill filters of moderate size with an average filter mesh.

Habits and habitat. The tadpoles of Hypsiboas atlanticus were found at the edge of the forest, in two sites, one of them formed by small puddles of water approximately one square meter and $0.2 \mathrm{~m}$ deep; the other site was a rain-filled puddle with a diameter about five square meters and $0.5 \mathrm{~m}$ in depth. At both sites the water was clear with a lot of sediment on the bottom and dense semi-aquatic vegetation. The tadpoles are benthonic, have cryptic coloration, and do not form aggregations.

The larvae of five of the nine species of the Hypsiboas punctatus group have been previously described: $H$. alemani (Mijares-Urrutia, 1992), $H$. cinerascens (DuELlMAN, 1978 (from Ecuador); HERO, 1990 (from Amazonas, Brazil); MuJAREs-UrRutia, 1993 (from Venezuela)), H. jimenezi (Myers \& Donnelly, 2008), $H$. punctatus (KenNy, 1969 (from Trinidad); Duellman, 1978 (from Ecuador); Hoogmoed, 1979 (from Suriname)), and $H$. sibleszi (Hoogmoed, 1979). The tadpole of $H$. punctatus rubrolineatus Brusquetti \& Lavilla, 2006 was described and recognized as a valid taxon based on LTRF differences (Kolenc et al., 2008). A summary of larval characteristics for tadpoles of $H$. punctatus group is given in table II. The external larval morphology of the $H$. punctatus group is similar and resembles that of a generalist type larvae (Altig \& Johnston, 1989). These characteristics include: body depressed in lateral view, caudal musculature not strongly marked, low caudal fins, and eyes dorsolaterally located, agree with the ecomorphological guild of benthic tadpoles that live in lentic environments. The only exceptions knows would be $H$. punctatus from Ecuador, that was reported to have laterally positioned eyes (Duellman, 1978), H. sibleszi, which was reported to inhabit lotic environments ("... the majority was calling from leafs and twigs above the water of slow flowing creeks...," HoogmoEd, 1979) and H. punctatus from Trinidad that was found in both habitats (KENNY, 1969).

Hypsiboas atlanticus, $H$. alemani, and $H$. sibleszi have a wide anal tube, formed by a skin-fold connecting 
Table II. Comparison of larval characters among species in the Hypsiboas punctatus group. Characters followed by the word "supposition" in parentheses were inferred from the illustrations, but not stated in the text by the authors. ( ${ }^{\mathrm{a}}$, MiJares-Urrutia (1992); ${ }^{\mathrm{b}}$, This study; ${ }^{\text {, }}$ Mijares-Urrutia (1993); d, Duellman (1978);, , Hero (1990); ${ }^{\mathrm{f}}$, Myers \& Donnelly (2008); ${ }^{\circ}$, Kenny (1969); ${ }^{\text {, }}$, Duellman (1978); i , Hoogmoed (1979); ', Kolenc et al. (2008); ${ }^{k}$, Hoogmoed (1979)).

\begin{tabular}{|c|c|c|c|c|c|c|}
\hline Species & Eyes & $\begin{array}{l}\text { Cutaneous } \\
\text { flap in nares }\end{array}$ & $\begin{array}{l}\text { Skin-fold } \\
\text { on the } \\
\text { anal tube }\end{array}$ & $\begin{array}{l}\text { Orientation of the oral } \\
\text { disc/presence of } \\
\text { submarginal papillae }\end{array}$ & $\begin{array}{l}\text { Labial tooth } \\
\text { row formula }\end{array}$ & $\begin{array}{c}\text { Habitats } \\
\text { types }\end{array}$ \\
\hline $\begin{array}{l}\text { H. } \text { alemani }^{a} \\
\text { (Rivero, 1964) }\end{array}$ & Dorsolateral & Yes & Yes & Ventral/no & $2(1-2) / 4$ & Pond \\
\hline $\begin{array}{l}\text { H. atlanticus }{ }^{\mathrm{b}} \\
\text { (Caramaschi \& Velosa, 1996) }\end{array}$ & Dorsolateral & Yes & Yes & Anteroventral/yes & $2(1,2) / 3(1)$ & Pond \\
\hline $\begin{array}{l}\text { H. } \text { cinerascens }^{c} \\
(\text { Spix }, 1824)\end{array}$ & Dorsolateral & Yes & $?$ & Ventral/no & $2(2) / 4(1)$ & $?$ \\
\hline H. cinerascens $^{\mathrm{d}}$ & Dorsolateral & $?$ & $?$ & Anteroventral/? & $1(1) / 2$ & Pond \\
\hline H. cinerascens $^{\mathrm{e}}$ & Dorsolateral & Yes & $?$ & $\begin{array}{l}\text { Ventral (supposition)/ } \\
\text { no (supposition) }\end{array}$ & $\begin{array}{l}2(1,2) / 3- \\
4(1)[2]\end{array}$ & $\begin{array}{c}\text { Pond and } \\
\text { streamside pond }\end{array}$ \\
\hline $\begin{array}{l}\text { H. jimenezi }{ }^{\mathrm{f}} \\
\text { (Señaris \& Ayarzagüena, 2006) }\end{array}$ & Dorsolateral & $\begin{array}{c}\text { Yes } \\
\text { (supposition) }\end{array}$ & $?$ & Ventral/yes & $\begin{array}{c}2 / 4 ; 3 / 4 ; 2 / 5 ; \\
3 / 5\end{array}$ & Pond \\
\hline $\begin{array}{l}\text { H. punctatus }{ }^{\mathrm{g}} \\
(\text { Schneider, 1799) }\end{array}$ & Dorsolateral & Yes & $?$ & $\begin{array}{c}\text { Anteroventral (supposition)/ } \\
\text { no (supposition) }\end{array}$ & $2(2) / 3$ & $\begin{array}{l}\text { Pond and } \\
\text { stream }\end{array}$ \\
\hline H. punctatus ${ }^{\mathrm{h}}$ & Lateral & $?$ & $?$ & Anteroventral/? & $2(2) / 3$ & Pond \\
\hline H. punctatus ${ }^{\mathrm{i}}$ & Dorsolateral & Yes & $?$ & $\begin{array}{c}\text { Anteroventral (supposition)/ } \\
\text { no (supposition) }\end{array}$ & $2(1,2) / 3(1)$ & Pond \\
\hline $\begin{array}{l}\text { H. punctatus rubrolineatus }{ }^{\mathrm{j}} \\
\text { (Brusquetti \& Lavilla, 2006) }\end{array}$ & Dorsolateral & Yes & $?$ & Ventral/yes & $2(2) / 4(1)$ & $?$ \\
\hline $\begin{array}{l}\text { H. sibleszi } i^{k} \\
\text { (Rivero, 1972) }\end{array}$ & Dorsolateral & Yes & Yes & $\begin{array}{c}\text { Ventral (supposition)/ } \\
\text { no (supposition) }\end{array}$ & $2(2) / 5(1)$ & Stream \\
\hline
\end{tabular}

the body and the ventral fin; there is no comparative information about this character in other species of the group. The oral disc of $H$. atlanticus, $H$. cinerascens (from Ecuador) and $H$. punctatus have anteroventrally oral discs (ventrally in the others species), these differences can be correlated with habitat and feeding mechanics (Altig \& McDiarmid, 1999). Only $H$. cinerascens from Venezuela and $H$. jimenezi have a double row of marginal papillae (single row in the others species), submarginal papillae were reported for $H$. atlanticus, $H$. jimenezi, and $H$. punctatus rubrolineatus (absent in the others species). All tadpoles of the H. punctatus species group can be differentiated by a combination of oral disc features (i.e., LTRF, number of rows of marginal papillae, and presence/absence of submarginal papillae (Tab. II); $H$. atlanticus and $H$. punctatus from Suriname are differentiated from each other by the presence and absence of submarginal papillae, respectively. All species in the group possesses a projection on the medial rim of the external nares (except that this character has not been reported in $H$. punctatus and $H$. cinerascens from Ecuador) as previously reported for other species of the tribe Cophomantini (e.g., H. albomarginatus (Spix, 1824), Aplastodiscus albosignatus (Lutz \& Lutz, 1924), and A. albofrenatus (Lutz, 1924), Регхото \& CRUz, 1983). This extension may function as an external narial valve and may regulate or direct water current. This character needs further evaluation before it can be considered a synapomorphy for the tribe (FaIvovich et al., 2005)

The anatomy of the oral cavity was described for only two species of the Hypsiboas punctatus species group: H. cinerascens (HeURSEL \& HADDAD, 2007) and $H$. punctatus rubrolineatus (KolENC et al., 2008). Hypsiboas atlanticus seems to have two pair of lingual papillae, whereas Hypsiboas cinerascens and $H$. punctatus rubrolineatus were reported to have one pair of lingual papillae. Hypsiboas p. rubrolineatus has seven projections on the lateral ridge papillae whereas those of $H$. cinerascens were reported to have rugose margins; in $H$ atlanticus they are simple and conical. The presence of a high square-shaped median ridge with undulations on the ends, with lateral borders free of serrations, and one short papilla at each side of the base was considered diagnostic for the $H$. punctatus species group (KolenC et al., 2008). In H. atlanticus the median ridge is large but not tall, with papillae on its free edge, and a lateral border free of serrations only on the base. There are no papillae at the each side of the base. Tadpoles of the tribe Cophomantini possess a buccal roof with vacuities anterior to the internal nares (HEURSEL \& HADDAD, 2007), this character was suggested as a synapomorphy of the tribe (FAIVovich et al., 2005); the presence or absence could not be assessed in $H$. atlanticus.

NAPOLI \& CRUZ (2005) described the advertisement call of Hypsiboas atlanticus from Bahia (northeastern Brazil) and compared it with reported advertisement call of $H$. punctatus from other populations in South America concluding that: the calls of $H$. atlanticus and $H$. punctatus from Manaus (Amazonas, Brazil; HöDL, 1977), Santa Cecília (Ecuador, Duellman, 1978), and Puerto Almacén (Bolivia; MÁrQuEZ et al., 1993) are similar, which does not support $H$. atlanticus as a valid species, and analyses of the call of $H$. punctatus from Bolivia and French Guiana (MARTY \& GAUCHER, 1999; MÁrQUEZ et al., 2002; recordings commercially available) and one from Maranhão (Brazil; recorded by G. V. Andrade, pers. comm.) 
indicated the presence of at least three distinct species: $H$. atlanticus in Bahia, Brazil, H. punctatus in northern South America, and a potential undescribed third species occurring in Bolivia, Acre (Brazil) and the Chaco of Argentina. The present description of the tadpole of $H$. atlanticus provides additional support to the validity of this taxon.

Recently, $H$. punctatus was found to occur in the Atlantic Rain Forest from Southeastern and Northeastern Brazil (VAsConcelos et al., 2006), the same biome of $H$. atlanticus. Additional descriptions and illustrations of $H$. punctatus tadpoles and calls analyses from populations throughout South America are needed and may be helpful in determining the status of these populations.

Acknowledgments. We thank Ulysses Caramaschi (MNRJ) and an anonymous reviewer for hepful contributions on the manuscript; José A. Langone (MNHN) assisted us with relevant literature. This work was supported by Fundação de Amparo à Pesquisa do Estado de Alagoas (FAPEAL) (proc. 2002.08.110-02 and 2004.04.29864-02). RdS was supported by NSF award 0342918 .

\section{REFERENCES}

Altig, R. 1970. A key to the tadpoles of the continental United States and Canada. Herpetologica 26(2):180-207.

Altig, R. \& Johnston, G. F. 1989. Guilds of anuran larvae: relationships among developmental modes, morphologies, and habitats. Herpetological Monographs 3:81-109.

Altig, R. \& McDiarmid, R. W. 1999. Body plan: development and morphology. In: McDiarmid, R. W. \& Altig, R. eds. Tadpoles: The Biology of Anuran Larvae. Chicago, University of Chicago. p.24-51.

Caramaschi, U. \& Velosa, A. 1996. Nova espécie de Hyla Laurenti, 1768 do leste brasileiro (Amphibia, Anura, Hylidae). Boletim do Museu Nacional, Nova Série, Zoologia (365):1-7.

Duellman, W. E. 1974. A reassessment of the taxonomic status of some neotropical frogs. Occasional Papers of the Museu of Natural History, University of Kansas 27:1-27.

1978. The biology of an equatorial herpetofauna in Amazonian Ecuador. Miscellaneous Publication, University of Kansas 65:1-352.

Faivovich, J.; Haddad, C. F. B.; Garcia, P. A.; Frost, D. R.; Campbell, J. A. \& Wheeler, W. C. 2005. Systematic review of the frog family Hylidae, with special reference to Hylinae: phylogenetic analysis and taxonomic revision. Bulletin of the American Museum of Natural History 294:1-240.

Frost, D. R. 2009. Amphibian Species of the World: an Online Reference. Version 5.3. American Museum of Natural History. Available at: <http://research.amnh.org/ herpetology/amphibia/index.php>. Access on: 05.12.2009.

Gosner, K. L. 1960. A simplified table for staging anuran embryos and larvae with notes on identification. Herpetologica 16(3): 183-190.

Hero, J. M. 1990. An illustrated key to tadpoles occurring in the Central Amazon rainforest, Manaus, Amazonas, Brazil. Amazoniana 11:201-262.

Heursel, A. D' \& Haddad, C. F. B. 2007. Anatomy of the oral cavity of Hylid larvae from the genera Aplastodiscus, Bokermannohyla, and Hypsiboas (Amphibia, Anura): description and systematic implications. Journal of Herpetology 41:458-468.
HöLD, W. 1977. Call differences and calling site segregation in anuran species from Central Amazonian floating meadows. Oecologia 28:351-363.

Hoogmoed, M. S. 1979. Resurrection of Hyla ornatissima Noble (Amphibia: Hylidae) and remarks on related species of green tree frogs from the Guiana area. Notes of the herpetofauna of Suriname VI. Zoologische Verhandelingen 172:1-46.

Kenny, J. S. 1969. The Amphibia of Trinidad. Studies of the Fauna of Curaçao and other Caribbean Islands 108:1-78.

Kolenc, F.; Borteiro, C.; Alcalde, L.; Baldo, D.; Cardozo, D. \& FaIvovich, J. 2008. Comparative larval morphology of eight species of Hypsiboas Wagler (Amphibia, Anura, Hylidae) from Argentina and Uruguay, with a review of the larvae of this genus. Zootaxa 1927:1-66.

Márquez, R.; Riva, I. De la \& Bosch, J. 1993. Advertisement calls of Bolivian species of Hyla (Amphibia, Anura, Hylidae). Biotropica 25(4):426-443.

Márquez, R.; Riva, I. de la; Bosch, J. \& Matheu, E. eds. 2002. Sounds of frogs and toads of Bolivia. Barcelona, Alosa. (CD-ROM).

Marty, C. \& Gaucher, P. 1999. Sound guide to the tailles amphibians of French Guiana. Paris, Centre Bioacoustique (CD-ROM).

Mijares-Urrutia, A. E. M. 1992. Sobre el renacuajo de Hyla alemani Rivero (Anura: Hylidae). Acta Biologica Venezuelica 13(3-4):35-39.

1993. The tadpole of Hyla granosa (Anura: Hylidae) from southeastern Venezuela. Revista Chilena de Historia Natural 66:143-147

Myers, C. W. \& Donnelly, M. A. 2008. The summit herpetofauna of Auyantepui, Venezuela: report from the Robert G. Goelet American Museum-Terramar Expedition. Bulletin of the American Museum of Natural History 308:1-147.

NAPOLI, M. F. \& CRUZ, I. C. S. 2005. The advertisement call of Hyla atlantica Caramaschi \& Velosa, 1996, with considerations on its taxonomic status (Amphibia, Anura, Hylidae). Arquivos do Museu Nacional 63(2):283-288

Peixoto, O. L. \& Cruz, C. A. G. 1983. Girinos de espécies de Hyla do grupo "albomarginata" do sudeste brasileiro (Amphibia, Anura, Hylidae). Arquivos da Universidade Federal Rural do Rio de Janeiro 6(2):155-163.

SÁ, R. O. DE; Langone, J. A. \& Segalla, M. V. 2007. The tadpole of Leptodactylus notoaktites Heyer, 1978 (Anura, Leptodactylidae). South American Journal of Herpetology 2(1):69-75.

Santos, E. M. \& Carnaval, A. C. O. Q. 2002. Anfibios anuros do Estado de Pernambuco. In: Tabarelli, M. \& Silva, J. M. C. eds. Diagnóstico da Biodiversidade de Pernambuco. Recife, SECTMA/Massangana. p.529-536.

SeÑaris C. J. \& Ayarzagüena, J. 2006. A new species of Hypsiboas (Amphibia; Anura; Hylidae) from the Venezuelan Guayana, with notes on Hypsiboas sibleszi (Rivero 1972). Herpetologica 62:308-318.

Silvano, D. \& Pimenta, B. V. S. 2002. Hyla atlantica. Herpetological Review 33(3): 145

VAsconcelos, T. S.; SAntos. T. G. \& Haddad, C. F. B. 2006 Amphibia, Anura, Hylidae, Hypsiboas punctatus: distribution extension and filling distribution gaps. Check List 2(2):61,62.

WASSERSUG, R. J. 1976. Oral morphology of anuran larvae: terminology and general description. Occasional Papers of the Museum of Natural History, University of Kansas 48: $1-23$.

WASSERsug, R. J. \& Heyer, W. R. 1988. A survey of internal oral features of leptodactyloid larvae (Amphibia: Anura). Smithsonian Contributions to Zoology 457:1-99. 